臨床サイドから見た望まれる加温機器

\author{
不 破 信 和
}

愛知県がんセンター放射線治療部

キーワード：温熱療法, 望まれる加温機器

\section{1.は じ め に}

現在, 温熱療法は欧米諸国のみならず, 我が国 においても数年前に見られた盛り上がりがみられ ず，その臨床上の意義，役割について再検討がさ れているように思われる。

15 年程前に免疫療法が頭打ちとなった癌治療 成績を打破すべく癌治療の第 4 の柱として登場し, 多くの基礎研究，臨床研究がされたが，現在に至 ってもその有効性についてはまだ明確にされてお らず，温熱療法も現在の状況が続けば免疫療法と 同じように癌治療の柱として将来とも認知されな い可能性がある。温熱療法も免疫療法も正常組織 に対する障害は比較的少なく, 癌組織への抗腫瘍 効果の機序は従来の治療にない特徴をもつ優れた 方法であり, 現在頭打ちとなっている癌治療成績 を break through させ得る可能性をもつユニーク な治療法と考えられている. しかしながら両者と も理論的には非常に優れた方法であるものの, 免 疫療法でいえば薬剤が, 温熱療法でいえば加温機 器に問題点があり, 今後この点を改善しないこと には新たな癌治療の柱にはなりえないものと思わ れる。つまり, 温熱療法の将来はいかに臨床上優 れた加温機器が開発されるかどうかで決まるとい っても過言ではない.もし現在使用されている加

1995 年 12 月 21 日受付 (依頼原稿)
温機器が理工学的な限界でこれ以上の進展が望め ないならば, 温熱療法のみならず, 癌治療全体の 大きな不幸と云ってよい，その意味で理工学者や メーカーの責任は極めて大きいと云えよう.

本論に入る前に, 温熱療法は本当に癌治療に有 効なのであろうか. このことをまず論じてみたい. もし有効でなければ，全ての議論が無に帰してし まうからである。

筆者は放射線治療医であり，本論文で述べる意 見はあくまで 1 放射線治療医の立場からみた意見 であることを初めにお断りしておく，独断と偏見 に満ちた意見であるかもしれないが，癌治療の現 場で苦闘している 1 医師としての切実な意見であ り，また温熱療法の有効性については確信しては いるものの加温機器の現状には歯ぎしりしている 者の率直な意見でもある。

\section{2. 温熱療法は本当に有効なのか?}

温熱療法の有効性を述べた報告は多く ${ }^{1)-3)}$, そ の意味では臨床上有効性が実証されていない免疫 療法より臨床上の有効性は証明されているといっ てよい．筆者自身は 1985 年より $\mathrm{RF}$ 誘電加温に 始まり, レンズアプリケーター付マイクロ波加温, $\mathrm{RF}$ 誘電加温による組織内加温, ND-YAG レー ザーを利用した温熱療法（レーザーサーミア）， $\mathrm{RF}$ 誘電加温による腔内加温を経験した，放射線 治療単独では制御出来そうもない大きな腫瘍や, 
放射線抵抗性腫瘍である肉腫に対しても著効例を 多く経験しており，少なくとも放射線治療と温熱 療法を組み合わせ，腫瘍全体に良好な加温が得ら れた場合の有効性は明らかであると断言できる。

Table 1 Primary effect for breast cancer

\begin{tabular}{|c|cc|ccc|}
\hline & \multicolumn{2}{|c|}{$\begin{array}{c}\text { Combined } \\
\text { hyperthermia }\end{array}$} & \multicolumn{3}{|c|}{ Irradiation alone } \\
\hline & CR & PR & CR & PR & NC \\
\hline $\begin{array}{c}\text { Max tumor size } \\
(\mathrm{cm})\end{array}$ & & & & & \\
-7 & 1 & 0 & 8 & 1 & 1 \\
-10 & 4 & 1 & 1 & 6 & 0 \\
$10-$ & 5 & 2 & 1 & 0 & 1 \\
\hline
\end{tabular}

Table 1 に当施設での局所進行乳癌における放射 線治療単独と温熱療法を組み合わせた場合の抗腫 瘍効果を示すが， $7 \mathrm{~cm}$ 以上の大きな腫瘍に対する 温熱併用の有効性は明らかである. Fig. 1 に進行 乳癌（正確には肉腫）の 1 例を示すが, 従来の放 射線治療単独では CR（100\% 縮小） どころか PR (50\%以上の縮小) を得られるのも困難と考えら れる例であり, 温熱治療併用の有効性を如実に示 すものである.

Table 2 は当科に打ける年次別症例数の推移を 示すが，ここ最近 4 年間の症例数は以前より増加
Table 2 Number of cases according to the year

\begin{tabular}{|c|c|}
\hline & number of cases \\
\hline $1982-1984$ & 24 \\
$1985-1986$ & 39 \\
$1987-1988$ & 27 \\
$1989-1990$ & 24 \\
$1991-1992$ & 85 \\
$1993-1994$ & 80 \\
\hline
\end{tabular}

している．温熱療法を選択するかどうかは筆者以 外にも複数の医師により決定されており，少なく ても当科において温熱療法は実験的治療ではなく, ルーチン治療の 1 つとして定着しているといって 良いであろう。しかしながら対象例の多くは乳癌 の再発例や再発頭䅡部癌の䅡部リンパ節転移例で あり，その治療目的は姑息的であり，根治目的と してはまだルーチン治療として行われていないの が現状である。

初めの問い, 温熱療法は有効なのか? 。この答 えはYESといってよい。ただし腫瘍全体が充分 に加温されていることと, 放射線治療あるいは化 学療法との併用が必要条件となる。またこの治療 なくして根治治療が成り立たない領域は残念なが ら 1 つをいという事実もつけ加えなければなら ない.

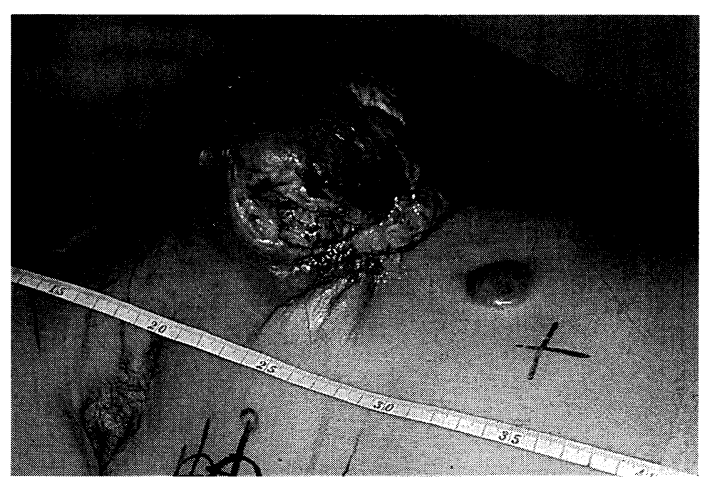

pre treatment

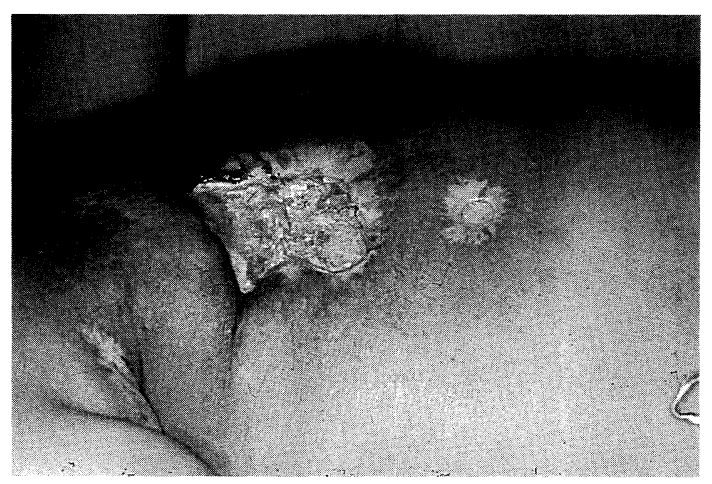

post treatment

Fig. 1 breast sarcoma 


\section{3. 現在使用されている加温機 器のどこに問題があるのか ?}

現在わが国で臨床で広く用いられている加温機 器としては深部腫瘍に対しては RF 誘電加温装置 が，表在性腫瘍に対してはマイクロ波加温装置が ある. $\mathrm{RF}$ 誘電加温装置の問題点としては脂肪層 の過熱による脂肪層での疼痛, 骨周囲組織への $\mathrm{RF}$ の収束による骨周囲の疼痛があげられる，脂 肪層の厚い欧米人では前者が $\mathrm{RF}$ 誘電加温の最大 のネックとなっており, 今後も深部加温装置とし ては世界的な普及は望めないものと思われる。

Table 3 The correlation between the thickness of adipose tissue and the degree of the pain in hypogastrium

\begin{tabular}{|c|rcc|}
\hline $\begin{array}{c}\text { The thickness of adipose } \\
\text { tissue }(\mathrm{cm})\end{array}$ & -2 & $2.1-3$ & $3.1-$ \\
\hline Pian scale & & & \\
Grade 0 & 13 & 0 & 0 \\
Grade 1 & 3 & 0 & 0 \\
Grade 2 & 1 & 2 & 1 \\
Grade 3 & 0 & 1 & 2 \\
\hline
\end{tabular}

Grade 0 none

Gradel requires no care

Grade2 requires any care

Grade3 unable to continue the hyperthermia

Table 3 に自験例での子宮䅡癌例での CT で計測 した脂肪層の疼痛との関係を示すが, 脂肪層が $3 \mathrm{~cm}$ 越えると加温の続行が極めて困難となり, 充分な治療は出来なくなる，その他に，空気のあ る臓器では空気層の周囲に RF の収束が起こるた め胸部の加温では間質性肺炎，腹部の加温では消 化器の炎症が発症することがある ${ }^{4)}$. 深部加温機 器として RF 誘電加温装置は症例によっては良好 な加温結果が得られるものの, 上記の問題点があ り, これらの問題点を解決しない限り, 深部腫瘍 に対するスタンダードな治療にはなり難いものと 思われる。

マイクロ波加温装置の問題点としては加温深達
性の悪さが最大の欠点であったが，㐘地らの開発 したレンズアプリケーター方式は従来のマイクロ 波加温装置に較へ，約 2 倍の深達性が得られてお り，その意味では画期的な加温装置である ${ }^{5)}$.こ の装置の問題点としてはアプリケーターが大型と なるため，時に鎖骨上窩や頚部でのアプリケー ターの密着が悪くなり良好な加温が得られないこ とがあることと, 深部深達性は良好であるが横方 向への加温域が狭いことである，本装置は患者の 負担も少なく, 胸部など平坦な部位での加温は極 めて良好であり, その意味で皮膚科領域の悪性腫 瘍に最も適しており，皮膚の悪性腫瘍の多い欧米 で本装置が使用されれば，非常に高い評価を受け るものと考えられる。当科での温熱療法の $2 / 3$ の 症例は本装置を使用しており，上記の問題点はあ るものの, 特に乳癌術後の比較的大きな胸壁再発 例に対してはルーチン治療として定着している. 䅡部などの解剖学的に凹凸のある部位への密着性 の改善, より横方向へ加温域の広いアプリケー ターの開発が今後必要と思われる。

その他の加温装置としては組織内加温法があげ られるが，我が国ではまだ実験段階である。組織 内加温は最も加温効率が優れた方法であり, 腫瘍 に限局した加温が可能である ${ }^{6)}$. 問題点としては 侵襲的であること, 加温部位が限定されることが あげられる．最近では国産の加温機器の治験も開 始されており, 小線源治療あるいは術中照射との 併用も可能であり, 加温適応部位は限られるもの の可能性を秘めた加温法である.

\section{4. 今後臨床で必要とされる 加温機器について}

それでは今後臨床で必要とされる加温機器はど のようなものであろうか? 。理想をいえば体内の どの部分に腫瘍があっても目的とする温度に非侵 襲的に自由に腫瘍のみ加温できる機器であるが, 遠い将来に夢をはせるとして, 現在, および近い 将来に臨床で必要とされる機器について述べたい 
と思う。

a . 温熱療法と放射線治療を同時に施行出来る機 器 (方法) の開発

温熱療法と放射線治療の組み合わせは殺細胞機 序においてお互いに相補的な関係にあることは良 く知られている。その組み合わせの夕イミングは 主に技術的な問題から継時併用で行われており，

この場合の熱増感比 (TER: thermal enhancement ratio）は約 1.5 とされるが, 最も TER の高いの は同時併用であり，その TER は約 2.5 とされて いる7).この場合注意しなければいけないことは 正常組織も腫瘍と同様に加温され，また放射線照 射をされるならば, 正常組織の TER も 2.5 とな り, 治療効果比 (TGF: therapeutic gain factor; 腫瘍組織の TER/正常組織の TER）は 1 となり, 継時併用時に較べてむしろ低下してしまう ${ }^{8)}$. 従 って同時併用の場合は可及的に腫瘍のみ加温をし， 腫瘍のみ放射線照射をすることが必要となる。 我々の施設では 1993 年より膵藏癌に対し, 従来 より行ってきた術中照射に加え, $\mathrm{RF}$ 誘電加温に よる組織内加温を併用している ${ }^{9)}$. 治療のプロト コールは組織内加温は 30 分施行し, 加温 15 分後 に25Gy の照射を施行するというものである. 加 温機器の故障もあり, 現在まで 7 例にしか施行し ていないが， 2 年以上経過例が 2 例あり，特に問 題となる副作用もない. Fig. 2 に治療時の写真を

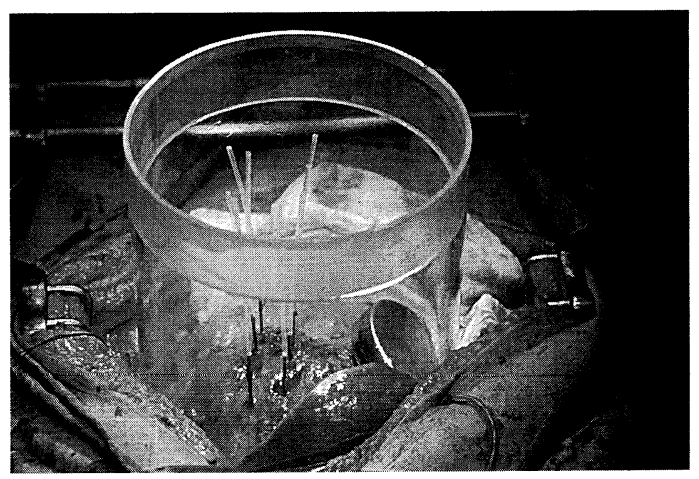

Fig. 2 Intraoperative interstitial hyperthermia on pancreas cancer

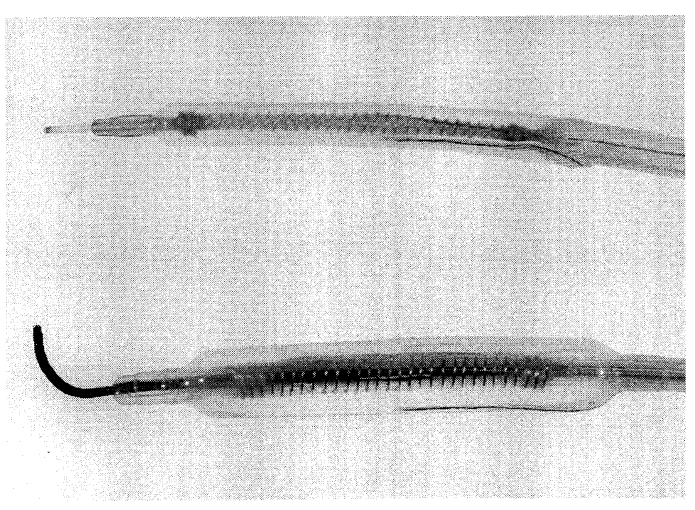

Fig. 3 The applicator tip for delivering intraluminal hyperthermia Above: A 6 Fr. radiation source tube is inserted into the center of the applicator which has a $10 \mathrm{~mm}$ diameter baloon. Below. An endoscope $2.2 \mathrm{~mm}$ in diameter is inserted into the center of the applicator which has a $15 \mathrm{~mm}$ diameter balloon.

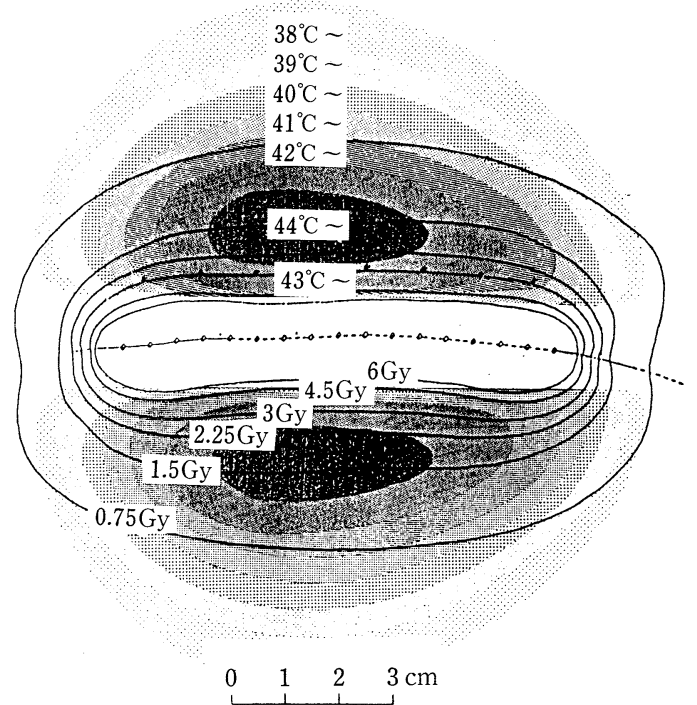

Fig. 4 Intraluminal dose distribution and thermal distribution

示すが，術中照射単独の治療成績をどれくらい改 善出来るか期待される.

食道癌に刘しても RF 誘電加温による腔内加温 装置と高線量率のIridiumを用いる RALS (remote afterloading system) を同時に治療出来る システムを開発し, 1995 年より三重大学との共 
同研究を開始している ${ }^{10)}$. Fig. 3 にアプリケー ターを, Fig. 4 に加温分布と線量分布を示す.こ の治療の最大の利点は Fig. 4 からわかるように 放射線線量の減衰する領域が加温分布が最も高く なって抢り，放射線と温熱を同時に施行すること により TER を上げるばかりでなく，放射線の減 衰する領域は温熱療法で補うことが出来る点にあ る.まだ Phase 1 の段階であるが，抗腫瘍効果は 良好であり，今後アプリケーターの改良，至適投 与量の検討など多くの解決すべき問題点があるが, 手術不能進行食道癌の治療成績を大きく break through させうる可能性を有する治療と考えてい る.この治療法が他に応用出来る領域としては子 宮癌があげられる，この領域は外照射と腔内照射 の組み合わせで良好な治療成績が得られているが, 本治療の採用により，より高い局所効果ばかりで なく, 照射線量の減量による慢性障害の軽減が期 待出来よう.

b. 加温域は小さいけれど，ある領域に限局して 高温の得られる治療法の開発

42 度前後の温熱療法単独では充分な抗腫瘍効 果が得られないことは良く知られている。一方 レーザーサーミア（Nd-YAG laser による加温治 療）では 15 分前後の加温で，しかもこの治療単 独で良好な治療効果が得られることが知られてい る ${ }^{11)}$ 、筆者も1991 年より使用する機会を得, 種々の領域の悪性腫瘍対し, 放射線治療との併用 で，あるいはレーザーサーミア単独で治療を施行 した，乳癌再発例に対してのレーザーサーミア単 独治療（治療時間は 10 15 分）では腫瘍径 $8 \mathrm{~mm}$ 未満例では全例に CR が得られており, 腫瘍内の 温度がある温度以上（恐らく45 度以上）で加温 できれば，温熱療法単独で，しかも短時間で満足 すべき治療効果が得られるということを示唆する ものであろう．またこの症例の多くが局所麻酔だ けで外来で治療できたことも特筆すべきである. 腫瘍のみ高温が得られるということは腫瘍の大き さにある程度の限界を持たせるということではあ
るが，複数のアプリケーター（レーザーサーミア でいえばレーザーチップ）を用いて同時に複数点 の加温ができれば，ある程度の大きさの腫瘍も対 応でき，口腔内の $\mathrm{T} 1$ （2 cm 以内）の腫瘍であれ ば外来で虫歯の治療程度の簡便さで治療出来るに 違いない．現在は腫瘍に直接加温機器を挿入する 方法でしか腫瘍内を高温にする方法はないが，体 外からある限られた領域のみ高温にする技術が開 発されれば，温熱療法単独でも有効な治療となる ものと思われる。

\section{c . 肺癌を充分加温出来る機器の開発}

我が国のみならず全世界的にみて今後最も問題 となる悪性腫瘍は症例の多さ, 治療の困難さから 見て肺癌と考えられる。黒石らによると 1990 年 の肺癌死亡率は男女とも 10 年後には 1.3〜 1.4 倍 に，20 年後には 1.6 倍になると予測されており， 肺癌の治療対策は急務であることが分かる(12)、肺 癌の治療の第一選択は手術であるが，過半数の症 例は手術が出来ず，その場合は放射線治療あるい は化学療法の併用が施行されるが，最近の 10 年 間に目だった治療成績の向上は見られず頭打ちの 感がある，肺癌に対する温熱療法の試みは我が国 で RF 誘電加温を用いて行われており，厳密な意 味での randomized trial ではないが，放射線治療 単独成績に比べ良好な治療成績が報告されてい $3^{13)-15)}$.

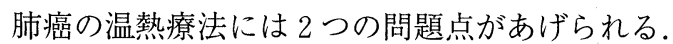
1 つは温度測定，もう 1 つは肺組織自体が空気の かたまりであるため RF 誘電加温で加温した場合, $\mathrm{RF}$ が縦隔や胸壁に収束するため肺実質の中にあ る腫瘍に対しては加温効率が悪いことである．温 度測定の問題については外部より温度計を直接腫 瘍に刺入することは一部の腫瘍を除き気胸の危険 性があり，このことが肺癌に温熱療法が積極的に 行われなかった理由でもあった。これについては $\mathrm{X}$ 線透視下に気管支鏡を用いて TBLB（trans bronchial lung biosy) の要領で温度計を挿入すれ ば容易に腫瘍辺縁の温度は測温可能であることを 
筆者自身確認しており, 臨床使用に際しての問題 点はないものと思われる. 胸部加温効率の低い $\mathrm{RF}$ 誘電加温でも症例を選択すれば良好な治療効 果が得られており, より胸部加温効率の良い加温 機器が開発されれば臨床の現場で肺癌で苦闘して いるものにとって大きな福音となるに違いない.

\section{5.お わ り に}

$\mathrm{RF}$ 誘電加温, レンズアプリケーター付マイク 口波加温は我が国で独自に開発され，臨床応用さ れた加温機器で, 多くの治療実績がある. 優れた 治療効果も多く報告されており, 今後も多くの施 設で加温機器の中心として使用されるに違いない. しかしながら上述したような問題点があり，その 改善, あるいは新しい加温機器の開発は急務であ る。

温熱療法には Biology is with us, physics is againt us. という有名な言葉があるが，私は Biology and clinical effect is with us, physics is still against us. と付け加えたい. 最後にもう 1 度強調 したい. 温熱療法の未来は理工学（者）の努力 (成果)により決まる.

\section{文献}

1) Perez, C. A., Nussbaum, G., Emami, B., et al.: Clinical results of irradiation combined with local hyperthermia. Cancer 52: 1597-1603, 1983.

2) 不破信和：局所進行，局所再発乳癌に対する温熱 療法併用放射線治療成績. 日本医放会誌. 48 : 45-55，1988.

3）松田忠義, 高橋正治, 築山嚴ほか：深在性腫瘍に 対する温熱併用放射線治療一多施設による共同研 究の解析一. 日本ハイパーサーミア誌. 6 : 411-424, 1990.
4）不破信和，森田浩三，室加守ほか：8MHz RF 誘電 加温による温熱療法の障害について。 日本八 イパーサーミア誌. 6：197-203，1990.

5）菊地真, 二川佳央, 吉田翼ほか：電波レンズ型 $430 \mathrm{MHz}$ マイクロ波加温装置の開発に関する研究 (第 2 報）一実用的加温システム（HTS-100）の試 作。開発一。日本ハイパーサーミア誌. 4 : 163-172, 1988.

6）山田哲也，不破信和，室加守ほか： $R F$ 組織内加温 装置の臨床使用経験。日本ハイパーサーミア誌. 8： 126-135, 1992.

7) Overgaard, J., Nielsen, O. S., Lindegaard JC: Biological basis for rational design of clinical treatment with combined hyperthermia and radiation. NATO, ASI, Ser E. 127: 54-79, 1987.

8) Overaard, J.: The current and potential role of hyperthermia in radiotherapy. Int J Radiat Oncol Biol Phys. 16: 535-549, 1989.

9）室加守, 不破信和, 森田浩三ほか：RF 組織内加温 専用装置 (Minerve) の使用経験, 術中照射同時加 温時における諸問題について，日本ハイパーサー ミア誌，8：236，1992.

10）不破信和，野本由人，庄司一寅ほか：食道癌に対 する腔内加温同時併用腔内照射治療. 日本医放会 誌, 55：993-995, 1995.

11）不破信和：レーザーサーミア，検査と技術，21： 465-467, 1993.

12）黑石哲生，広瀬加緒瑠，富永祐民ほか：日本にお けるがん死亡 (1950-1990), がん. 統計白書（富 永祐民．他)，篠原出版，東京，171-185，1993.

13) Terasima, H., Nakata, S., Yamasita, S., et al.: Pancoast tumour treated with combined radiotherapy and hyperthermia a preliminary study. INT J HYPERTHERMIA, 7: 417-424, 1991.

14）平塚純一, 三枝智恵子, 今城吉成：再発肺癌に対 する温熱併用放射線治療後の局所効果と予後の関 係. 日本医放会誌，53：86-90，1993.

15) Karasawa, K., Muta, N., Nakagawa, K., et al.: Thermoradiotherapy in the treatment of locally advanced nonsmall cell lung cancer. Int J Radiat Oncol Biol Phys, 30: 1171-1177, 1994. 


\title{
Ideal hyperthermia apparatus from the clinician's viewpoint
}

\author{
Nobukazu Fuwa \\ Department of Radiotherapy, Aichi Cancer Center Hospital
}

\section{Summary:}

What kinds of instruments are required in the future?

(1) Instruments for simultaneous thermotherapy and radiotherapy.

Simultaneous thermotherapy and radiotherapy achieve the most effective antitumor effect. As normal tissue sensitivity is also increased, selective radiotherapy and thermotherapy delivery to the tumor is necessary. We obtained good results in treating pancreatic and esophageal cancers with simultaneous thermotherapy and radiotherapy.

(2) Instruments effecting at least $45 \mathrm{C}$ in tumors only.

This treatment is only effective for small tumors at $2-3 \mathrm{~cm}$, in which case thermotherapy alone may be an effective teratment.

(3) Instruments effective for lung cancer.

Apart from surgery, other treatments for lung cancer are ineffective.

Some Japanese facilities are experimenting with combined Rf capacitive thermotherapy and radiotherapy for lung cancer.

Although the result is better than radiotherapy alone, a satisfactory level has not been reached. RF capacitive heating is not the best suited delivery system for lung cancer. Instruments that achieve effective hyperthermia in lung cancer await development.

The future of thermotherapy depends on the development of effective instruments, for which the responsibility of engineers is great.

Key words: Hyperthermia, Ideal apparatus 